Joanna Zach iD https://orcid.org/0000-0002-7425-3540

Uniwersytet Jagielloński

joanna.zach@uj.edu.pl

\title{
Listy, rozmowy, spotkania - uwagi wstępne
}

\section{Letters, Conversations, Meetings - Introductory Notes}

Coraz chętniej czytamy cudze listy, jak gdyby równoważąc fakt, że coraz mniej ich piszemy. Tradycyjna, by nie powiedzieć: staroświecka, korespondencja staje się przede wszystkim świadectwem mijającej epoki, dokumentem pewnego typu relacji międzyludzkiej ukształtowanej przez pismo. Jeśli odwieczna sztuka epistolografii na naszych oczach odchodzi do lamusa, to zmienia się również perspektywa naszej lektury. Czego szukamy, co odkrywamy dziś w prywatnej korespondencji pisarzy, filozofów, artystów i ludzi kultury?

Ostatnie lata przyniosły wielką obfitość książek zawierających listy i rozmowy: ukazuje się korespondencja Tadeusza Różewicza (niedawno z Karlem Dedeciusem i Ryszardem Przybylskim), wychodzą kolejne tomy korespondencji Wisławy Szymborskiej (z Kornelem Filipowiczem, Joanną Kulmową, Stanisławem Barańczakiem), trwa wieloletnia edycja listów Jerzego Giedroycia, czekamy na kolejne tomy listów Józefa Czapskiego. Tytuły książek można by długo wymieniać, zarówno te z kręgu rodzimej kultury (jak choćby Czestaw Mitosz, Jan Btoński. Listy 1958-1997, Gdańsk 2019), jak i te, które czytamy w przekładach (vide Emila Ciorana Listy do kraju, Warszawa 2020). Są one komentarzem, ale i częścią dzieła, świadectwem życia i tekstem kultury.

Niniejszy numer skupia się na tych świadectwach - w wymiarze prywatnym i publicznym, w horyzoncie indywidualnej twórczości i w szerszym spectrum zjawisk, określających relacje między ludźmi, sposoby i formy komunikacji. Przede wszystkim chodzi tutaj o listy i opublikowane rozmowy, ale „rozmowa”, a w szczególności „spotkanie”, to pojęcia niejako przechodnie, oznaczające również aspekt każdej wymiany myśli, każdej komunikacji. Warto je ponownie przemyśleć, być może bowiem utraciły swoją oczywistość. Warto do nich powrócić $\mathrm{w}$ świetle dokonującej się przemiany - w świetle procesów zachodzących wewnątrz kultury od dawna i w obliczu globalnych wydarzeń Anno Domini 2021. 
Rozważania wokół zarysowanych powyżej problemów podzieliliśmy na dwie części: pierwszą z nich wypełniają odpowiedzi na ankietę „Kontekstów Kultury", drugą - artykuły naukowe. Na koniec zaś publikujemy listy Leny Vinzenz do Jerzego Stempowskiego. W części pierwszej odstąpiliśmy od zwyczajowych norm dyskursu naukowego, by oddać głos przedstawicielom różnych dziedzin kultury literackiej, osobom, których opinie mają znaczący wpływ na nasze rozumienie współczesnych zjawisk. Na tę ankietę zechciało odpowiedzieć czworo autorów: Teresa Walas, Maria Poprzęcka, Piotr Matywiecki i Tadeusz Sławek. Z ich wypowiedzi, mniej lub bardziej osobistych, wyłania się pewien obraz komunikacji epistolarnej w dobie późnej nowoczesności. Nie jest to, jakby się mogło wydawać, obraz nostalgiczny; raczej krytyczne, wielostronne ujęcie ewolucji form językowych - oralności i piśmienności - jako mediów międzyludzkiego dialogu.

Pytania, jakie postawiliśmy w ankiecie, miały być jedynie punktem wyjścia do indywidualnej refleksji, dlatego też forma odpowiedzi jest za każdym razem odmienna. Ankietowani zwracają uwagę na status listu jako „wielkiego gatunku literackiego", który odegrał istotną rolę u początków śródziemnomorskiej tradycji (Maria Poprzęcka); na „zubożenie, jakie przez uwiąd tradycyjnej epistolografii dotyka kulturę rozumianą jako drogę formowania i samoformowania się człowieka" (Teresa Walas); na inne, być może ważniejsze, sposoby komunikowania samych siebie i nawiązywania relacji (Piotr Matywiecki); wreszcie - na antropologiczny wymiar listu jako „ręko-dzieła”, które sprzeciwia się mechanizacji życia i mechanizacji kultury (Tadeusz Sławek). Na ogół jednak nasi respondenci szukają przeciwwagi dla tego, co utracone, podkreślając, że potrzeba komunikacji nie zanika, a nawet - paradoksalnie - może się objawiać jako reakcja na kryzys tradycyjnych mediów.

W części drugiej znalazły się cztery artykuły, z których właściwie tylko dwa dotyczą epistolografii w sensie ścisłym (autorstwa Agnieszki Bielak i Kajetana Mojsaka). Agnieszka Bielak, przygotowująca książkę o doświadczeniu religijnym w twórczości Józefa Czapskiego, zajęła się obrazem Polski w korespondencji artysty. Odnosząc się zarówno do wydanych, jak i wciąż czekających na edycję listów autora $\mathrm{Na}$ nieludzkiej ziemi, autorka tego szkicu zarysowuje dramat tożsamości, która nie mieści się w dwudziestowiecznych ramach przynależności narodowej. Warto zwrócić uwagę, że - niezależnie od poruszanych problemów - listy Józefa Czapskiego są zawsze próbą przywołania realnej obecności, próbą budowania relacji opartej na zbliżeniu osób. Z kolei listy Franza Kafki, którym przygląda się Kajetan Mojsak, to wyraziste przykłady „ekskomunikacji" odbiorcy. W korespondencji adresowanej do kobiet, Felicji Bauer i Mileny Jasenskiej, list staje się fetyszem, domeną idealistycznych projekcji, oddalających, a w konsekwencji niszczących perspektywę rzeczywistego obcowania.

Zgodnie z intencją redakcji zamieściliśmy w tym zeszycie także teksty, które nasz temat przewodni interpretują nieco szerzej. Artykuł Agaty Schulc-Woźniak poświęcony jest bliskiej relacji pomiędzy córką i matką; relacji, która wyraża 
się w wierszach. „Zótte czerénie” - matce. Córczyne wiersze Joanny Pollakówny to przykład wielostronnej analizy poetyckiego medium jako języka transgresji - niemożliwej, a jednak w jakimś sensie rzeczywistej komunikacji między światami żywych i umarłych. Na koniec tej sekwencji publikujemy tekst Wojciecha Browarnego pt. „Kartki” Tadeusza Różewicza. Autor tego artykuły wydobywa, formułuje i poddaje refleksji jeden z ważniejszych aspektów warsztatu pisarskiego autora Niepokoju.

Poza ramami tematu przewodniego znalazły się domykające całość numeru recenzje. Łukasz Tischner pisze o książce Jerzego Jarzębskiego Gry poetyckie $i$ teatralne, odsłaniając mniej znane oblicze wybitnego badacza i krytyka. Z kolei Anna Szóstak przygląda się uważnie dwóm edycjom krytycznym utworów Jana Brzechwy w opracowaniu Moniki Urbańskiej i Jowity Podwysockiej-Modrzejewskiej. Wreszcie ostatnią pozycję stanowi omówienie publikacji, która się ukazała w Nowym Jorku, a poświęcona jest nowym odczytaniom twórczości Witolda Gombrowicza przez badaczy z różnych kręgów kulturowych: Gombrowicz in Transnational Context: Translation, Affect, and Politics. Książkę tę zrecenzowała dla nas Katarzyna Żabicka.

Joanna Zach Redaktor prowadzaca zeszytu 